\title{
The Optimized Path of Financial Ecological Environment in the Post- crisis Era
}

\author{
Zhang Yun ${ }^{1,2, a}$, Xu Di-long ${ }^{1,3}$ \\ ${ }^{1}$ College of Finance and Statistics, Hunan University, Changsha, Hunan, 410079, China \\ ${ }^{2}$ Hunan Chemical Vocational Technology College, Hunan University, Zhuzhou, Hunan, 412000, \\ China \\ ${ }^{3}$ Institute of Finance, Guangzhou University, Guangzhou, Guangdong, 510006, China \\ ahnhyzyun@163.com
}

Keywords: Medium-sized and small enterprises; ecological environment; optimization; path

\begin{abstract}
The development of financial industry must be supported by external environment. A series of external environment, such as financial infrastructures, governmental supervision and credit system etc., provides resources and system safeguard for the development of financial industry. Meanwhile, it is necessary to value the restriction of system limit and resource constraint on financial development.
\end{abstract}

\section{Introduction}

Global economy has already had the good development momentum since the financial crisis in 2008, even if it hasn't gotten rid of recession thoroughly. In the "post-crisis era", the development of global economy will be faced with more opportunities and challenges. The developmental practice of our financial industry proves that the development of financial industry is not promoted at a balanced mode. The development process also brings a series of problems, such as expansion of income gap, shortage of equality in financial services, dilemma of SME financing and bubblization of financial development, thus reform of financial system has been a hotspot in the society. It is urgent to solve the financial dilemma of "dualization" in our financial structure: inequality in urban and rural financial resource allocation and unbalanced regional financial development. As a result, to optimize our financial ecological environment is the primary path to solve our financial dilemma.

\section{Connotations of Financial Ecological Environment}

Financial ecology is a concept of bionics. It is the objective environment constituted by a series of internal and external environment for survival of financial industry. In essence, it is a mutually associated and complicated environment system constituted by investors, financial intermediaries, financiers and sub-systems of subjects. The optimal state of financial ecology doesn't mean to make every financial entity reach the optimal state, respectively, but makes financial entities mutually coordinate, interact and promote. The financial ecological system is mainly composed of financial ecological entities and financial ecological environment.

A. Coverage of financial services: Though our financial industry is developed rapidly, the "binary" financial ecological structure in urban and rural areas still exists. Moreover, remote areas can't enjoy the diversified financial services.

B. Inequality of financial product supply: with the constant development of our financial industry, financial product categories present the abundant and favorable development. Innovative financial products, such as Yuebao, pawn, P2P and insurance, etc., have already make the public experience convenience of financial services.

C. Insufficient financial facilities and financial institutions: By comparing with western developed countries, our financial facilities and financial institutions still have a large difference. According to financial survey of the World Bank in 2008, there were only 52.5 ATMs per square kilometer in China. Every million of people only had 38 ATMs. In Britain, these data were 
1044.6ATMs and 424.5ATMs, respectively. The difference between these two countries can be more than 10 times. In addition, our financial institutions are also obviously insufficient, especially for remote areas.

D. Imperfect development of financial credit system: The development of our financial credit system has lots of problems, entity credit imperfection and shortage of external credit restriction mechanism. In addition, credit system and credit environment can't be improved effectively, resulting in difficult optimization in external environment of financial ecology.

E. Shortage of financial incentive policy: In order to promote prosperity and development of our financial industry, the nation formulates a series of policy documents for financial development, but policy effects are not obvious (financial ecological elements are shown in Table 1).

Tab. 1 Composition of Financial Ecological System

\begin{tabular}{|c|c|c|}
\hline $\begin{array}{l}\text { Financial } \\
\text { ecological } \\
\text { system }\end{array}$ & $\begin{array}{l}\text { Primary index } \\
\text { level }\end{array}$ & Secondary index level \\
\hline \multirow{9}{*}{$\begin{array}{l}\text { Financial } \\
\text { ecological } \\
\text { environment } \\
\text { index system }\end{array}$} & $\begin{array}{l}\text { General economic } \\
\text { conditions }\end{array}$ & $\begin{array}{l}\text { Social economic structure, economic development level, economic system, } \\
\text { economic policy, and degree of economic marketization }\end{array}$ \\
\hline & $\begin{array}{c}\text { Development } \\
\text { status of financial } \\
\text { industry }\end{array}$ & $\begin{array}{l}\text { Depth of financial development, competition situation of financial } \\
\text { industry, overall development level of financial market, and credit status of } \\
\text { financial enterprises }\end{array}$ \\
\hline & $\begin{array}{l}\text { Development } \\
\text { status of financial } \\
\text { enterprises }\end{array}$ & $\begin{array}{l}\text { Scale and benefits of financial enterprises, governance status of financial } \\
\text { enterprises, construction of financial enterprise system, and credit level of } \\
\text { financial enterprises }\end{array}$ \\
\hline & $\begin{array}{c}\text { Judicial } \\
\text { environment }\end{array}$ & $\begin{array}{l}\text { Legal system of property right, sound degree of laws and regulations, and } \\
\text { financial judicial efficiency }\end{array}$ \\
\hline & $\begin{array}{l}\text { Financial } \\
\text { supervision level } \\
\text { of local } \\
\text { government }\end{array}$ & $\begin{array}{l}\text { Local financial strength, project approval and management, governmental } \\
\text { administrative intervention, supervision efficiency, and governmental } \\
\text { information sharing and transparency }\end{array}$ \\
\hline & $\begin{array}{l}\text { Social credit } \\
\text { status }\end{array}$ & $\begin{array}{l}\text { General credit level, development status of credit grading organization, } \\
\text { social credit management, and credit supervision }\end{array}$ \\
\hline & $\begin{array}{l}\text { Development } \\
\text { status of financial } \\
\text { intermediaries }\end{array}$ & $\begin{array}{l}\text { The number of intermediaries, management level of intermediaries, } \\
\text { business ability of intermediaries, scale and strength of intermediaries }\end{array}$ \\
\hline & $\begin{array}{c}\text { Financial } \\
\text { safeguard system }\end{array}$ & $\begin{array}{l}\text { Policy supporting strength, financial insurance policy, and construction of } \\
\text { financial equipment and facilities }\end{array}$ \\
\hline & $\begin{array}{l}\text { Financial } \\
\text { infrastructure } \\
\text { construction }\end{array}$ & $\begin{array}{l}\text { The number of financial institutions and construction of network finance } \\
\text { platform }\end{array}$ \\
\hline
\end{tabular}

In the financial ecological system, as the fundamental condition of financial development, financial infrastructures determine the breadth of financial ecological system directly. The development of financial industry and development status of financial enterprises and financial intermediaries determine the diversified degree of financial ecological system. The constant perfection of governmental financial supervision level, financial legal system, financial safeguard system and social credit status is beneficial to optimize external environment of financial ecological system, so as to maintain internal balance of ecological system.

To imitate natural ecological system operation and internal and external interaction mechanism can construct the dynamic regulation mechanism of financial ecological system(dynamic coupling regulation mechanism of financial ecological system is shown in Figure 1). 


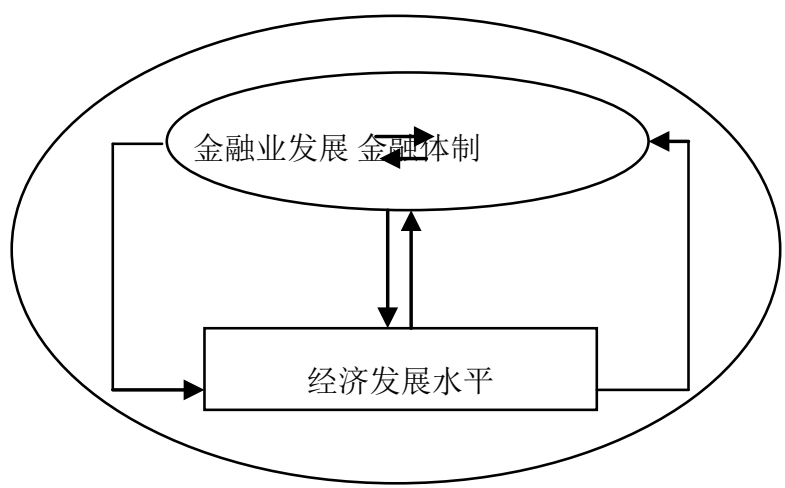

Fig. 1 Dynamic Coupling Regulation Mechanism of Financial Ecological System

\section{Construction of Financial Ecological Environment Evaluation Index System}

About the constructive methods of financial ecological environment evaluation index system and practical finance in China, the author establishes the comprehensive evaluation index system of our financial ecological environment and divides it into three levels of index system. The primary indexes mainly include economic environment, financial development, system environment and sociocultural environment. Economic environment is composed of economic development level, industrial structure optimization, degree of economic vitality and social life quality. Financial development environment is composed of financial scale, financial depth, financial market development, financial efficiency, and policy-based financial development. System environment is expressed as governmental economic behavior, administrative environment, legal environment and social security environment, etc. Social culture is expressed as population quality, integrity level and mass autonomous, etc. Afterwards, the author subdivides it into 33 tertiary indexes for evaluation, as shown in Table 2:

Tab. 2 Financial Ecological Environmental Evaluation Index System

\begin{tabular}{|c|c|c|}
\hline Primary indexes & Primary indexes & Tertiary indexes \\
\hline \multirow{4}{*}{$\begin{array}{l}\text { Economic } \\
\text { environment }\end{array}$} & $\begin{array}{c}\text { Economic } \\
\text { development level } \\
\mathrm{X} 1\end{array}$ & $\begin{array}{l}\text { Annual growth rate of gross production value, gross production } \\
\text { value/GDP }\end{array}$ \\
\hline & $\begin{array}{l}\text { Industrial structure } \\
\text { optimization X2 }\end{array}$ & $\begin{array}{l}\text { Secondary industry output/primary industry output, tertiary industry } \\
\text { output/primary industry output }\end{array}$ \\
\hline & $\begin{array}{c}\text { Degree of economic } \\
\text { vitality X3 }\end{array}$ & $\begin{array}{l}\text { Fixed investment growth rate, investment rate, consumption rate, } \\
\text { increase value of township enterprises/gross production value }\end{array}$ \\
\hline & $\begin{array}{l}\text { Social life quality } \\
\mathrm{X} 4\end{array}$ & $\begin{array}{l}\text { Actual per capita net income growth rate, per capita income gap of } \\
\text { urban and rural residents, and family's Engel coefficient }\end{array}$ \\
\hline \multirow{5}{*}{$\begin{array}{l}\text { Financial } \\
\text { development }\end{array}$} & Financial scale X9 & $\begin{array}{l}\text { Total assets of financial institutions/gross production value, } \\
\text { employment rate of financial industry }\end{array}$ \\
\hline & Financial depth X10 & Loan/gross production value \\
\hline & $\begin{array}{l}\text { Financial market } \\
\text { development X11 }\end{array}$ & $\begin{array}{l}\text { Direct finance amount/gross production value, direct finance } \\
\text { amount/loan }\end{array}$ \\
\hline & $\begin{array}{l}\text { Financial efficiency } \\
\text { X12 }\end{array}$ & $\begin{array}{l}\text { Transfer rate of savings and investment, loan-to-deposit ratio and } \\
\text { return on assets }\end{array}$ \\
\hline & $\begin{array}{c}\text { Policy-based } \\
\text { financial } \\
\text { development X13 }\end{array}$ & $\begin{array}{l}\text { Agricultural expenditure of national finance/national financial } \\
\text { expenditure, overall policy-based agricultural loan/overall loan }\end{array}$ \\
\hline \multirow{3}{*}{$\begin{array}{l}\text { System } \\
\text { environment }\end{array}$} & $\begin{array}{c}\text { Governmental } \\
\text { economic behavior } \\
\text { X5 }\end{array}$ & $\begin{array}{l}\text { Financial income/gross production value, system environment, and } \\
\text { financial expenditure gap }\end{array}$ \\
\hline & & Claim settlement rate \\
\hline & $\begin{array}{l}\text { Legal environment } \\
\text { X6 }\end{array}$ & The number of lawyers per 10000 people \\
\hline
\end{tabular}




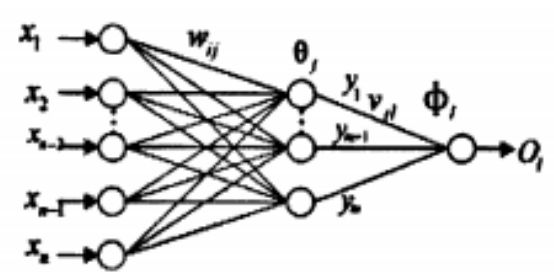

Fig. 2 Three Layers of BP Artificial Neural Network Structure

The evaluation on financial ecological environmental status is a comprehensive complicated and multi-factor problem with incomplete information. in the paper, the evaluation index of describing financial ecological environment is regarded as a network inputX $\left(X_{1}, X_{2}, \ldots, X_{n}\right)$. Corresponding comprehensive evaluation results are used as the output $\mathrm{O} 1$ of BP artificial neural network. The larger output is, the better financial ecological environment will be, vice versa. Sufficient samples are used to train the network. Sample set for training network is obtained by experts' evaluation on the financial ecological environment, thus the reliability has the higher authority. When training error reaches the expected errors, training is finished. After stable network weights wij and vji are trained, the financial ecological environment evaluation model based on BP artificial neural network is established. In this way, it can deal with corresponding new data, providing BP output results. Comprehensive evaluation of BP artificial neural network for financial ecological environment is conducted. For simplification, the author applies the above-mentioned secondary indexes as the input vector $\mathrm{X}=\left(\mathrm{X}_{1}, \mathrm{X}_{2}, \ldots, \mathrm{X}_{\mathrm{n}}\right)$. Comprehensive evaluation results are regarded as output O1. Input is shown in Table 3-8. Firstly, evaluation standards of financial ecological environment are designed. Data sample set is collected. Design of evaluation set has a decisive action on objective accuracy of evaluation results. The order of evaluation has some ambiguity. In the paper, evaluation set is set up as good, preferable, general, poor and worse. The evaluation interval is shown in Table 3.

Tab. 3 Level Evaluation of Financial Ecological Environment

\begin{tabular}{|c|c|c|c|}
\hline Order of evaluation & $\begin{array}{c}\text { Comprehensive } \\
\text { evaluation }\end{array}$ & Order of evaluation & $\begin{array}{c}\text { Comprehensive } \\
\text { evaluation }\end{array}$ \\
\hline Good & $0.8 \leq 0_{1} \leq 1$ & Poor & $0.2 \leq 0_{1}<0 \mathrm{~A}$ \\
\hline Preferable & $0.6 \leq 0_{1}<0.8$ & Worse & $0<0_{1}<\mathrm{n} 2$ \\
\hline General & $0.4 \leq 0_{1}<0.6$ & & \\
\hline
\end{tabular}

Based on the order of evaluation, the author applies a questionnaire survey and invites experts and scholars(expert $\mathrm{A}, \mathrm{B}, \ldots, \mathrm{L}, \mathrm{M}, \mathrm{N}, \mathrm{O}$ ) who engage in finance to grade secondary evaluation indexes of financial ecological environment. In order to maintain basic consistent evaluation scale and obtain more reasonable results, as well as consider the secondary index composition and financial practice, the paper sets up relatively uniform qualitative standards and collects 15 evaluation forms of experts to do credit analysis on 15 experts' evaluation results. By applying the Cronbach'sQ coefficient, the reliability coefficient is 0.882 .12 of evaluation forms are used for training neural network. The other 3 forms evaluate the trained network to obtain specific data. Secondly, expected value is calculated. Sample data are conducted normalization processing. The analytic hierarchy process is applied to weight every index. Experts make a comparison between secondary indexes of financial ecological environment(the specific process refers to the practice in "confirming financial efficiency evaluation index weight coefficient vector" in section 4 of the chapter). Based on the judgment matrix table 3-10 for pairwise comparison of expert $\mathrm{A}$, calculation of expert $\mathrm{B}$ and L's judgment matrixes is expressed as $(\mathrm{X}, \ldots, \mathrm{Xi}$, with corresponding $\mathrm{V}, \ldots, \mathrm{Vi})$ to simplify the process. The scoring of expert B, C, ..., L is disposed in the same way to obtain the relative weight of secondary index in financial ecological environment, as shown in Table 3. In order to avoid from covering middle and small numerical information in original data by large numerical information, positive indexes with larger index value are conducted normalization processing for difficult constriction of network. The processing equation is shown as follows: 


$$
x_{F}=\frac{x_{i}-\min \left(x_{i n}\right)}{\max \left(x_{i n}\right)-\min \left(x_{i n}\right)}
$$

Tab. 4 Secondary Evaluation Index Weight in Financial Ecological Environment

\begin{tabular}{|c|c|c|c|c|c|}
\hline \multicolumn{2}{|c|}{ Indexes } & Weights & \multicolumn{2}{|c|}{ Indexes } & Weights \\
\hline $\mathrm{X} 1$ & Economic development level & 0.189 & $\mathrm{X} 9$ & Financial scale & 0.042 \\
\hline $\mathrm{X} 2$ & $\begin{array}{ll}\text { Industrial } & \text { structure } \\
\text { optimization } & \end{array}$ & 0.083 & $\mathrm{X} 10$ & Financial depth & 0.060 \\
\hline X3 & Degree of economic vitality & 0.081 & $\mathrm{X} 11$ & $\begin{array}{l}\text { Financial market } \\
\text { development }\end{array}$ & 0.039 \\
\hline $\mathrm{X} 4$ & Social life quality & 0.101 & $\mathrm{X} 12$ & Financial efficiency & 0.087 \\
\hline $\mathrm{X} 5$ & $\begin{array}{l}\text { Governmental economic } \\
\text { behavior }\end{array}$ & 0.041 & $\mathrm{X} 13$ & $\begin{array}{l}\text { Policy-based } \\
\text { financial } \\
\text { development }\end{array}$ & 0.025 \\
\hline $\mathrm{X} 6$ & Legal environment & 0.042 & $\mathrm{X} 14$ & Population quality & 0.021 \\
\hline $\mathrm{X7}$ & Social safeguard environment & 0.048 & $\mathrm{X} 15$ & Credit development & 0.041 \\
\hline $\mathrm{X} 8$ & Property right system & 0.090 & $\mathrm{X} 16$ & Mass autonomy & 0.024 \\
\hline
\end{tabular}

With normalization process, the network is the three layers of BP neural network. The calculation formula of hidden nodes is shown as follows:

$$
n_{H}=\sqrt{n+m}+a=15
$$

By programming with MATLAB7.0, the three layers of BP neural network structure with risk evaluation are established. 12 sample data are put in the network for training. After 7534 times of training, the network has a good convergence effect. The target error is 0.0001 .

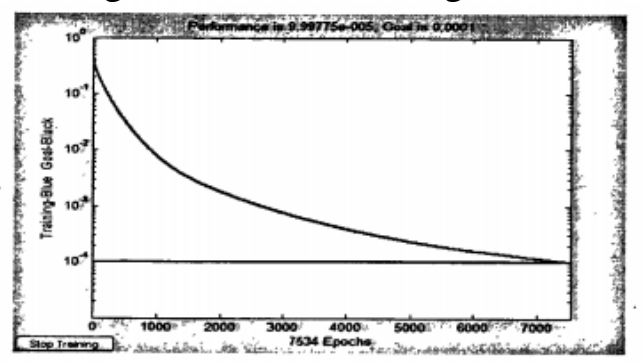

Fig. 3 Error Decline Curve of Network Training

The training value is inputted into the trained network to output training results and to obtain analogue value. The trained network performance is tested. Results are shown in Table 5:

Tab. 5 Analog Results and Expected Results after Network Training

\begin{tabular}{|l|l|l|l|l|l|l|l|l|l|}
\hline $\begin{array}{l}\text { Analog } \\
\text { value }\end{array}$ & 0.518 & 0.449 & 0.533 & 0.339 & 0.443 & 0.449 & 0.348 & 0.395 & 0.34 \\
\hline $\begin{array}{l}\text { Expected } \\
\text { value }\end{array}$ & 0.52 & 0.44 & 0.54 & 0.32 & 0.45 & 0.45 & 0.36 & 0.38 & 0.35 \\
\hline Error & -0.002 & 0.013 & -0.004 & 0.018 & -0.008 & 0.002 & -0.012 & 0.013 & -0.006 \\
\hline $\begin{array}{l}\text { Error } \\
\text { rate(\%) }\end{array}$ & -0.38 & 2.93 & -0.8 & 5.7 & -1.73 & 0.38 & -3.3 & 3.37 & -1.86 \\
\hline
\end{tabular}

After inputting into the trained network, output is obtained as $0.8261,0.6759,0.4619$. This is the calculated results for normalization data. After finishing neural network operation, data are outputted in the area of original data. Anti-normalization processing is conducted correspondingly. The processing formula is shown as follows:

$$
x_{i}=X_{i}^{*}\left(\max \left(x_{i n}\right)-\min \left(x_{i n}\right)\right)+\min \left(x_{\text {in }}\right)
$$

Results of anti-normalization processing are 0.3010, 0.2880 and 0.2694. By making a comparison with expected value, the Table 6 is shown as follows.

\begin{tabular}{|l|l|l|l|}
\hline Evaluation value & 0.3010 & 0.2880 & 0.2694 \\
\hline Expected value & 0.31 & 0.27 & 0.28 \\
\hline Error & -0.01 & 0.02 & -0.01 \\
\hline
\end{tabular}


The Table 6 shows that evaluation errors are kept in the controllable range, so it can be used as the evaluation basis. With the simple calculation, it shows that the mean of the above-mentioned evaluation results is 0.29 . It can be observed from the above-mentioned evaluation standards, order of financial ecological environmental evaluation is "poor", indicating that subjective judgment of experts on financial ecological environment is basically consistent with the status described in the last section objectively, namely financial ecological environment is fragile. As a result, it is necessary to optimize our financial ecological environment by adjusting and improving internal factors in financial ecological environment.

\section{Optimization of Our Financial Ecological Environment}

By analyzing development status and problems of our financial ecological environment, components of our financial ecological system and combining with the development status of our financial industry, the author proposes the optimal path to promote financial ecological environment for developing our financial industry.

A. Transformation of traditional financial institutions: Traditional financial institutions mainly refer to banks, including national banks, large-scale stock-holding banks, urban commercial banks and policy banks. Traditional financial institutions often own abundant capital strength, abundant management experience, broader market coverage, and advanced operation level.

B. Development of financial insurance business and realization of financial risk socialization: the existence of financial risks is one of the important barriers to hinder prosperity of financial industry. The development of financial insurance can withstand financial market risks and maintain financial stability to some extent.

C. Diversified financial services: In addition to basic financial services, it must provide insurance, trust, lease and guarantee according to financial market demands.

D. Sound financial supervision mechanism and functional supervision: Financial supervision departments should transfer ways of financial supervision and promote financial supervision to transfer from departmental supervision to functional supervision. Supervision departments should coordinate effectively, reduce supervision shortage and occurrence of multi-head supervision and improve service efficiency of supervision organizations.

E. Social credit system construction: It must construct the uniform credit information sharing data platform for enterprises and individuals, realize credit information sharing to supervise social credit status timely and dynamically, and know about credit status of enterprises and individuals timely to reduce credit risks. In addition, it is necessary to greatly develop credit grading institutions, standardize operation mode of credit grading institutions, reinforce integrity incentive mechanism of credit grading institutions, promote effective fulfillment responsibilities of credit grading institutions, reinforce punishment and award dynamics of credit deficiency market behaviors, perfect functions of credit supervision institutions, establish sound laws and regulations for credit supervision and strengthen credit market supervision.

\section{Reference}

[1] Li Shengdao, Wang Jing and Wang Yao, Financial Ecological Environment, Capital Structure and Corporate Growth [J], Forum on Science and Technology in China, 2014, 05: 106-111;

[2] Wei Zhihua, Zeng Aimin and Li Bo, Financial Ecological Environment and Corporate Financing Restriction-Based on the Empirical Study on Chinese Listed Companies[J], Accounting Research Study, 2014, 05: 73-80+95;

[3] Zhou Jiong and Wei Peijia, Evaluation Study on Provincial Financial Ecological Environment [J], Journal of Northwest University (Philosophy and Social Science), 2012, 01: 123-126;

[4] Shi Yarong and He Zerong, the Study on Rural Financial Ecological Environment Construction in Urban and Rural Integration Process [J] Economist, 2012, 03:74-79; 
[5] Wang Laixi, Effect Analysis of Financial Ecological Environment on Financial Industry and Regional Economic Development-Based on Effects and Problems of Financial Ecological Environment in Central Plains Economic Region[J], Business Economy, 2012, 02: 147-150;

[6] Wu Qingtian and Chen Wei, Empirical Study on Correlation between Rural Financial Ecological Environment and Financial Efficiency-Based on Typical Relevant Analysis and Granger Causality Test [J], System Engineering, 2012, 03: 76-84 